\title{
Quantitative Analysis of the Peripheral Blood Cytotoxic T Lymphocyte Response in Patients with Chronic Hepatitis C Virus Infection
}

\author{
Barbara Rehermann, ${ }^{\star}$ Kyong-Mi Chang, ${ }^{\star}$ John G. McHutchison, ${ }^{\ddagger}$ Robert Kokka, ${ }^{\S}$ Michael Houghton, ${ }^{\S}$ and Francis V. Chisari ${ }^{\star}$ \\ $*$ Department of Molecular and Experimental Medicine, The Scripps Research Institute, La Jolla, California 92037; ${ }^{\ddagger}$ Division of \\ Gastroenterology/Hepatology, The Scripps Clinic and Research Foundation, La Jolla, California 92037; and ${ }^{\S}$ Chiron Corporation, \\ Emeryville, California 94608
}

\begin{abstract}
Hepatitis C virus (HCV)-specific cytotoxic T lymphocytes (CTL) are present in the peripheral blood and liver of chronically infected patients. The current study was performed to study the relationship between the strength of the CTL response, liver disease severity, and viral load. The results may be summarized as follows: first, using CTL precursor frequency (CTLpf) analysis to quantitate the peripheral blood CTL response, chronically infected patients were less strongly sensitized to a panel of well-defined $\mathrm{HCV}$ epitopes than they were to an epitope within the influenza matrix protein. Second, HCV-specific CTLpf did not correlate with disease activity or viral load in the majority of patients on a cross-sectional basis, although it did increase in three patients concomitant with sharp increases in liver disease. Finally, interferon therapy did not enhance the CTLpf against the HCV epitopes studied in these patients, indicating that its antiviral effect is independent of the CTL response. Since the HCV-specific CTLpf in the blood is actually quite low, the CTL may contribute to ongoing liver disease in these patients while being quantitatively inadequate to destroy all of the infected hepatocytes, thereby facilitating HCV persistence and contributing to chronic liver disease. (J. Clin. Invest. 1996. 98:1432-1440.) Key words: cytotoxic $\mathrm{T}$ lymphocyte $\cdot$ interferon $\cdot$ viral persistence $\cdot$ viral clearance $\bullet$ hepatitis $\mathrm{C}$ virus
\end{abstract}

\section{Introduction}

The hepatitis $\mathrm{C}$ virus (HCV) ${ }^{1}$ is a hepatotropic RNA virus that causes acute and chronic liver disease and hepatocellular carci-

B. Rehermann and K.-M. Chang contributed equally to this study and should be considered co-first authors.

Address correspondence to Francis V. Chisari, Department of Molecular and Experimental Medicine, SBR-10, The Scripps Research Institute, 10550 North Torrey Pines Road, La Jolla, CA 92037. Phone: 619-784-8228; FAX: 619-784-2160; E-mail: fchisari@scripps.edu

Received for publication 28 December 1995 and accepted in revised form 18 July 1996.

1. Abbreviations used in this paper: ALT, alanine aminotransferase; bDNA, branched chain DNA; CTL, cytotoxic T lymphocytes; CRI, CTL response index; CTLpf, CTL precursor frequency; HCV (or $\mathrm{HBV}$ ), hepatitis $\mathrm{C}$ (or B) virus.

J. Clin. Invest.

(C) The American Society for Clinical Investigation, Inc. 0021-9738/96/09/1432/09 \$2.00

Volume 98, Number 6, September 1996, 1432-1440 noma (1-6). It is generally believed that immune-mediated mechanisms, in particular HLA class I-restricted cytotoxic T lymphocytes (CTL), play an important role in viral clearance and disease pathogenesis in many viral infections $(7,8)$. In hepatitis $\mathrm{C}$ virus infection, however, HLA class I-restricted HCV-specific CD8+ CTL are detectable in the peripheral blood (9-14) and CTL clones have been isolated from the liver of chronically infected patients (15-17) and chimpanzees (18) despite persistent infection.

Thus, HCV can survive in the face of an intrahepatic and peripheral CTL response to its antigens. To investigate the basis for this observation, we quantitated the peripheral blood CTL response longitudinally in chronically infected patients treated with interferon and analyzed the relationship between the strength of the CTL response, liver disease activity, and viral load. To identify patients whose CTL responses to one or more of these peptides were strong enough to warrant CTL precursor frequency (CTLp $f$ ) analysis longitudinally by limiting dilution analysis, we screened $\mathrm{HCV}$-infected patients before interferon therapy with a panel of $10 \mathrm{HCV}$-derived epitopes. We now report that the CTL precursor frequency for individual $\mathrm{HCV}$ epitopes is actually quite low in the peripheral blood of chronically infected patients as compared to the CTLp $f$ for the influenza matrix epitope, and it is not enhanced by interferon therapy. Since in individual instances an increase in CTLp $f$ preceded a rise in serum alanine aminotransferase (ALT) activity, the results suggest that the HCV-specific CTL response contributes to liver disease pathogenesis, but they are unable to clear the virus in patients with chronic hepatitis.

\section{Methods}

Patient population. 9 HLA-A2-positive patients with chronic hepatitis C (Table I) and 15 HLA-A2-positive healthy, uninfected subjects were studied. The diagnosis of HCV infection was based on standard clinical parameters and serological assays using the secondgeneration (c200/c22-3) Ortho HCV ELISA test system (Ortho Diagnostic Systems, Inc., Raritan, N.J.). All patients displayed elevated ALT activity and histological evidence of chronic active hepatitis before interferon therapy. Three (patients 2, 6, and 7) had liver cirrhosis. Treatment with interferon followed the protocols described in Table I. A decrease of transaminases below the upper limit of the normal range was achieved in five (patients 1, 4, 5, 7, and 9) during and immediately after cessation of therapy and serum HCV RNA was undetectable by branched chain DNA (bDNA) analysis in the same five patients and by nested polymerase chain reaction in two (patients 1 and 4) at the end of interferon treatment. Patient 1 showed a sustained reduction of serum ALT activity and remained HCV RNA negative by bDNA analysis for 6 mo after discontinuation of therapy, while Patient 4 displayed only a temporary biochemical and virologic response. All subjects studied were repeatedly negative for antibodies to HIV and HBV. The study protocol was approved by the Human Subjects Committee at the Scripps Clinic and Research Foundation (La Jolla, CA). 


\begin{tabular}{|c|c|c|c|c|c|c|c|c|c|c|c|}
\hline \multirow[b]{3}{*}{ Patient } & \multirow[b]{3}{*}{ Age } & \multirow[b]{3}{*}{ Sex } & \multirow{3}{*}{$\begin{array}{l}\mathrm{HCV} \\
\text { genotype }\end{array}$} & \multirow[b]{3}{*}{ Anti-HCV } & \multicolumn{3}{|c|}{ Before interferon therapy } & \multirow{3}{*}{$\begin{array}{c}\text { Type of } \\
\text { Interferon Therapy }\end{array}$} & \multicolumn{3}{|c|}{ End of interferon therapy } \\
\hline & & & & & \multirow{2}{*}{$\begin{array}{c}\mathrm{ALT} \\
{[\mathrm{U} / \mathrm{liter}]}\end{array}$} & \multicolumn{2}{|c|}{ HCV-RNA } & & \multirow{2}{*}{$\begin{array}{c}\mathrm{ALT} \\
{[\mathrm{U} / \mathrm{liter}]}\end{array}$} & \multicolumn{2}{|c|}{ HCV-RNA } \\
\hline & & & & & & bDNA* & $\mathrm{PCR}^{\ddagger}$ & & & bDNA* & $\mathrm{PCR}^{\ddagger}$ \\
\hline 1 & 42 & $\mathrm{~F}$ & $1 \mathrm{a}$ & positive & 97 & 110 & & 1 & 27 & $<3.5$ & negative \\
\hline 2 & 41 & M & $1 \mathrm{a}$ & positive & 306 & 220 & & 1 & 94 & 63.9 & \\
\hline 3 & 37 & $\mathrm{~F}$ & $1 b$ & positive & 98 & 61 & & 3 & 133 & 159 & \\
\hline 4 & 37 & M & $1 \mathrm{a}$ & positive & 223 & $<3.5$ & 0 & 1 & 29 & $<3.5$ & negative \\
\hline 5 & 40 & M & $3 a$ & positive & 83 & 5 & & 1 & 30 & $<3.5$ & 2 \\
\hline 6 & 51 & M & $1 \mathrm{a}$ & positive & 217 & 113 & & 4 & 159 & 75 & \\
\hline 7 & 36 & M & $1 b$ & positive & 140 & 20 & & 2 & 48 & $<3.5$ & 3 \\
\hline 8 & 39 & M & $1 \mathrm{a}$ & positive & 75 & 33 & & 3 & 69 & 39.3 & \\
\hline 9 & 40 & M & $3 a$ & positive & 86 & $<3.5$ & 3 & 3 & 54 & $<3.5$ & 3 \\
\hline
\end{tabular}

*bDNA, branched chain DNA assay for HVC RNA quantitation in 100,000 genome equivalents/ml. *Semiquantitative PCR with serial 10-fold dilution of cDNA was performed when HCV RNA was not detected by bDNA. Results indicate the negative logarithm (base 10) of the highest 10-fold dilution that was positive in this assay. ${ }^{8}$ Type of interferon therapy: (1) $6 \mathrm{wk}$ oral prednisone (60, $40 \mathrm{and} 20 \mathrm{mg}$ each for $\left.2 \mathrm{wk}\right)$ followed by 3 million $\mathrm{U}$ IFN alpha 2b (Intron A) (Schering Plough Corp., Kenilworth, NJ) subcutaneously thrice weekly for 6 mo; (2) IFN alpha 2a (Roferon; HoffmanLaRoche), 6 million U subcutaneously thrice weekly for 6 mo; (3) 1-9 million U Monomethoxy-polyethylene glycol IFN alpha-2a (HoffmanLaRoche) subcutaneously weekly for 6 mo; and (4) 10 million U IFN alpha 1 (Alferon; Interferon Sciences Inc., New Brunswick, NJ) subcutaneously thrice weekly for 6 mo.

HLA typing. HLA typing of PBMC from patients and from normal donors was performed by complement-dependent microcytotoxicity using HLA typing trays purchased from One Lambda (Canoga Park, CA).

Synthetic peptides. A panel of peptides representing 10 previously identified HLA-A2-restricted HCV CTL epitopes $(12,19,20)$ and the influenza matrix peptide 58-66 (21) were selected for this study (Table II). Peptide sequences were derived from the nucleotide sequence of HCV-1 (22), which is genotype 1a. All peptides were synthesized with a free amine $\mathrm{NH}_{2}$ terminus and a free acid $\mathrm{COOH}$ terminus by Chiron Mimotopes (Clayton, Australia). Lyophilized peptides were reconstituted at $20 \mathrm{mg} / \mathrm{ml}$ in DMSO (Mallinckrodt Inc., Paris, KY) and diluted to $1 \mathrm{mg} / \mathrm{ml}$ with RPMI 1640 medium (Gibco Laboratories, Grand Island, NY).

Stimulation of PBMC with synthetic peptides. PBMCs were separated on Ficoll-Histopaque density gradients (Sigma Chemical Co., St. Louis, MO), washed three times in HBSS (Gibco Laboratories), resuspended in RPMI 1640 (Gibco Laboratories) supplemented with
$2 \mathrm{mM}$ L-glutamine, $10 \mathrm{mM}$ gentamycin, and $10 \%$ heat-inactivated human $\mathrm{AB}$ serum, and plated in a 96-well round bottom plate at $0.4 \times$ $10^{6}$ cells $/ 100 \mu \mathrm{l}$ per well. Synthetic peptides were added at $10 \mu \mathrm{g} / \mathrm{ml}$ to eight replicate cultures. On day 7, the cultures were transferred to a 96-well flat-bottom plate and, on days 7 and 14, restimulated with 10 $\mu \mathrm{g} / \mathrm{ml}$ peptide, $20 \mathrm{U} / \mathrm{ml}$ rIL-2 (Hoffmann-La Roche, Nutley, NJ), and $10^{5}$ irradiated (3,000 rad) autologous feeder cells. On days 3, 10, and $18,100 \mu \mathrm{l}$ of RPMI with $10 \%$ (vol/vol) human AB serum and rIL-2 at $10 \mathrm{U} / \mathrm{ml}$ final concentration was added to each well. Cultures were tested for peptide-specific cytolytic activity on day 21 .

Cytotoxicity assay. For all experiments, JY cell targets (HLAA2.1, B7, Cw7) were maintained in RPMI with $10 \%$ (vol/vol) heatinactivated FCS (Gibco Laboratories). Target cells were incubated overnight with synthetic peptides at $10 \mu \mathrm{g} / \mathrm{ml}$ and then labeled with $100 \mu \mathrm{Ci}$ of ${ }^{51} \mathrm{Cr}$ (Amersham Corp., Arlington Heights, IL) for $1 \mathrm{~h}$ and washed four times with HBSS. Cytolytic activity was determined in a standard 4 -h ${ }^{51} \mathrm{Cr}$ release assay using round-bottom 96-well plates containing 3,000 targets/well. Stimulated PBMCs from patients and

Table II. The Epitopes

\begin{tabular}{|c|c|c|c|c|c|c|c|}
\hline \multirow[b]{2}{*}{ Peptide } & \multirow[b]{2}{*}{ Protein } & \multirow[b]{2}{*}{ Amino acid position } & \multirow[b]{2}{*}{ Amino acid sequence } & \multicolumn{4}{|c|}{ Conservation by genotype (\%) } \\
\hline & & & & $1 \mathrm{a}^{*}$ & $1 \mathrm{~b}^{*}$ & $3 a^{*}$ & Reference \\
\hline 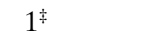 & Core & 35 & YLLPRRGPRL & 100 & 77 & 0 & 12,13 \\
\hline $2^{\ddagger}$ & Core & 131 & ADLMGYIPLV & 100 & 91 & 100 & $12-14$ \\
\hline 3 & E1 & 257 & QLRRHIDLLV & 100 & 0 & 0 & 14 \\
\hline $4^{\ddagger}$ & NS3 & 1073 & CINGVCWTV & 100 & 45 & 0 & 12,17 \\
\hline 5 & NS3 & 1169 & LLCPAGHAV & 67 & 0 & 0 & 12 \\
\hline $6^{\ddagger}$ & NS3 & 1406 & KLVALGINAV & 75 & 0 & 0 & 12 \\
\hline 7 & NS4 & 1789 & SLMAFTAAV & 100 & 0 & 0 & 12 \\
\hline 8 & NS4 & 1807 & LLFNILGGWV & 100 & 100 & 0 & 12,13 \\
\hline 9 & NS4 & 1851 & ILAGYGAGV & 100 & 91 & 100 & 13 \\
\hline 10 & IS5 & 2727 & GLQDCTMLV & 89 & 0 & 0 & 13 \\
\hline Flu epitope & Influenza-matrix & 58 & GILGFVFTLT & & & & 21 \\
\hline
\end{tabular}

*Number of published (Genbank/EMBL/DDBJ) full length sequences analyzed: 1a (6), 1b (11), and 3a (2). ${ }^{*}$ Epitopes chosen for CTL precursor frequency analysis. 
normal controls were tested at E/T ratios of 30:1-40:1. Percent cytotoxicity was determined from the formula: $100 \times[$ (experimental release - spontaneous release)/(maximum release - spontaneous release)]. Maximum release was determined by lysis of targets by detergent (10\% Triton X-100; Sigma Chemical Co.). In all instances, spontaneous release was $<25 \%$ of maximum release.

As previously described (23) the analysis of eight replicate cultures for each peptide allowed the strength of the CTL response to be expressed as the CTL response index (CRI). The CRI-P value is the sum of all specific cytotoxicities of the eight replicate cultures for a given peptide in a patient. The mean CRI-P values observed in the 15 normal controls are indicated at the bottom of Fig. 1. CRI-P values equal to or greater than the mean control value plus 3 SDs for each peptide were required for a CTL response to be considered positive. Positive responses are indicated in boldface type in Fig. 1 and the peptides chosen for limiting dilution analysis are underlined.

Limiting dilution analysis. Quantitative analysis of epitope-specific CTLp $f$ was performed in nine $\mathrm{HCV}$-infected patients and three uninfected healthy controls as previously described (24). To prepare antigen-presenting cells, autologous PBMCs were activated with
0.005\% Pansorbin cells (Calbiochem Corp., La Jolla, CA), with 20 $\mu \mathrm{g} / \mathrm{ml}$ Immunobeads (Rabbit anti-human IgM; Irvine Scientific, Santa Ana, CA) and $20 \mathrm{ng} / \mathrm{ml}$ human rec IL-4 (PharMingen, San Diego, CA) at $2 \times 10^{6}$ cells $/ \mathrm{ml}$ in RPMI 1640 supplemented with $2 \mathrm{mM}$ L-glutamine, $10 \mathrm{mM}$ gentamycin, and 5\% heat-inactivated FCS. On days $4-6$, they were washed in cold $0.9 \% \mathrm{NaCl}, 1 \% \mathrm{BSA}$, resuspended at $10^{7}$ cells $/ \mathrm{ml}$ in cold citrate phosphate buffer, (0.13 M L-citric acid (J.T. Baker, Inc., Phillipsburg, NJ), $0.06 \mathrm{M}$ sodium phosphate monobasic, pH3 (Sigma Chemical Co.), $1 \%$ BSA, and $3 \mu \mathrm{g} / \mathrm{ml} \beta 2 \mathrm{mi}-$ croglobulin for $2 \mathrm{~min}$ at $4^{\circ} \mathrm{C}$, washed with $5 \mathrm{vol}$ cold $0.15 \mathrm{M}$ sodium phosphate monobasic, pH 7.5, containing $3 \mu \mathrm{g} / \mathrm{ml} \beta 2$ microglobulin (Scripps Laboratories, La Jolla, CA) and $10 \mu \mathrm{g} / \mathrm{ml}$ peptide, and incubated with $50 \mu \mathrm{g} / \mathrm{ml}$ peptide, $30 \mu \mathrm{g} / \mathrm{ml}$ DNase (Sigma Chemical Co.), and $3 \mu \mathrm{g} / \mathrm{ml} \beta 2$ microglobulin for $4 \mathrm{~h}$ at $20^{\circ} \mathrm{C}$. After irradiation $(6,100$ $\mathrm{rad}), 10^{5}$ cells/well were plated in a 96-well round bottom plate and 400,000, 200,000, 100,000, and 50,000 autologous PBMCs were added in 24 replicates in $100 \mu \mathrm{l}$ RPMI 1640 supplemented with $2 \mathrm{mM}$ L-glutamine, $10 \mathrm{mM}$ gentamycin, and $10 \%$ heat-inactivated human $\mathrm{AB}$ serum. If a high CTL precursor frequency was expected, 100,000, $50,000,25,000$, and 12,500 PBMCs were added to each well. Cultures

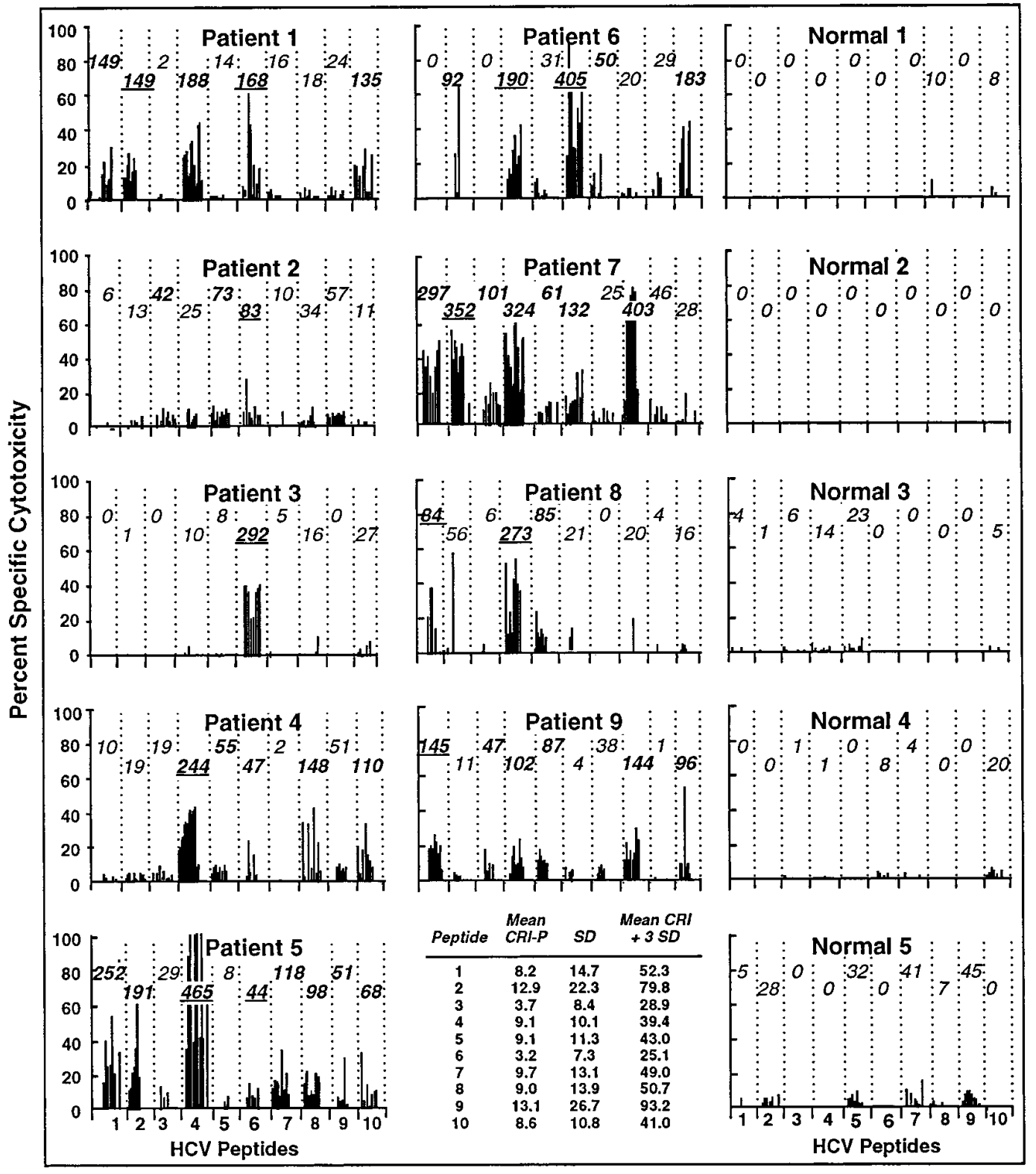

Figure 1. PBMC from 9 $\mathrm{HCV}$-infected patients (patients 1-9) and 15 healthy, uninfected controls were stimulated with $10 \mu \mathrm{g} / \mathrm{ml}$ of peptide for 3 wk as described in Methods and tested in a 4-h

${ }^{51} \mathrm{Cr}$ release assay against JY target cells prepulsed overnight with the same peptide. The bars represent the percent specific lysis in a $4-\mathrm{h}{ }^{51} \mathrm{Cr}$ release assay at an $\mathrm{E} / \mathrm{T}$ ratio of 30:1-40:1 for all 9 patients studied and for 5 representative controls (Normal 1-Normal 5). The CRI-P is displayed above the bars. The CRI-P corresponding to the peptides chosen for limiting dilution analysis are underlined. The table at the bottom center displays the mean \pm 3 SDs of the CRI for each peptide in the 15 normal controls. This number is used as the operational cut off for a positive CTL response in this study. 
were fed with $20 \mu \mathrm{l}$ rIL-7 (PharMingen) on day 7 and $20 \mu \mathrm{rIL}-2 \mathrm{ev}-$ ery $3 \mathrm{~d}$ to obtain a final concentration of $10 \mathrm{ng} / \mathrm{ml} \mathrm{rIL}-7$ and $10 \mathrm{U} / \mathrm{ml}$ IL-2. After restimulation with autologous, peptide-pulsed $(20 \mu \mathrm{g} / \mathrm{ml})$, irradiated (3,000 rad) adherent cells on day 12, a split-well CTL-assay with 3000 targets/well as described above, was performed on day 1719. Cultures were regarded as positive if the specific cytotoxicity was more than 2 SDs above the mean of the unspecific cytotoxicity of all cultures, and CTL precursor frequency was calculated using the maximum likelihood method (25). To follow changes in the HCV epitopespecific CTLp $f$ in individual patients over time, frozen PBMCs from different bleed dates were thawed, cultured, and tested for specific cytotoxicity in the same experiment.

$H C V$ RNA determination and HCV genotyping. RNA was extracted from $100 \mu \mathrm{l}$ of serum as previously described (26). Reverse transcription and nested polymerase chain reaction of the conserved 5 ' noncoding region was performed to establish the presence of $\mathrm{HCV}$ RNA (27). PCR products were analyzed on a $1.5 \%$ agarose gel and visualized by ethidium bromide staining. HCV RNA was quantitated in serum using the bDNA nucleic acid hybridization assay Quantiplex $^{\mathrm{TM}}$ HCV RNA Assay (Chiron Corp., Emeryville, CA) according to the manufacturer's instructions. Results were expressed as HCV genome equivalents per milliliter. Semiquantitative PCR was also performed using serial 10 -fold dilutions of the cDNA. The negative logarithm of the highest 10 -fold dilution of cDNA yielding a positive
Table III. HCV and Influenza CTLpf in Patients and Controls

\begin{tabular}{lcrr}
\hline Subject & HCV peptide & HCV & Flu \\
\hline & & & CTLpf* \\
Patients & & & \\
1 & 6 & 6.3 & 37.0 \\
2 & 6 & 3.2 & 22.8 \\
4 & 4 & 12.8 & 25.5 \\
Normal & & & \\
6 & 4 & 1.8 & 10.7 \\
7 & 4 & 0.3 & 74.0 \\
8 & 2 & 0.5 & 76.4 \\
& & & \\
\hline
\end{tabular}

*per $10^{6}$ PBMCs.

result was taken as the HCV RNA titer for each sample. HCV genotype in each patient was determined by the standard INNOLIPA assay (courtesy of Dr. Andrew Conrad, National Genetics Institute, Los Angeles, CA), using PCR-amplified viral nucleic acid and genotype-specific probes in the $5^{\prime}$ noncoding region (28).

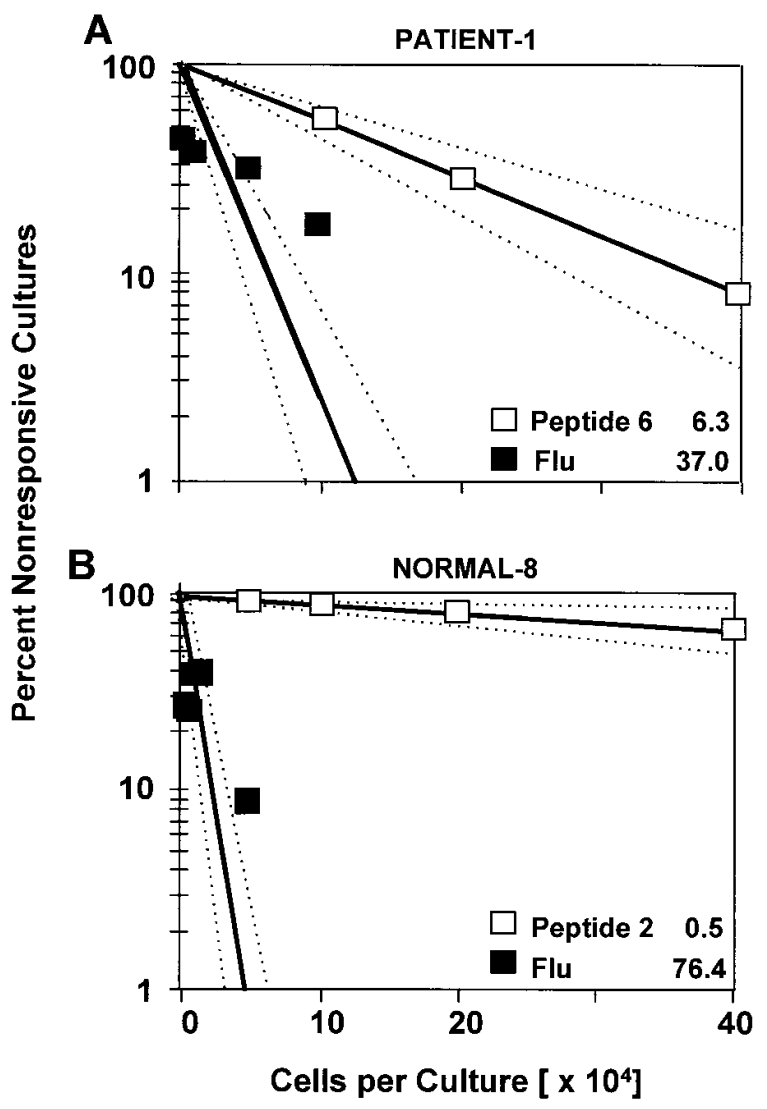

Figure 2. Precursor frequency of CTL specific for HCV-derived peptides $(\square)$ and for the influenza matrix epitope M58-66 (ם) in an $\mathrm{HCV}$-infected patient $(A)$ and a healthy, uninfected control $(B)$. An $\mathrm{HCV}$-derived peptide that was efficiently recognized by semiquantitative CTL analysis (illustrated in Fig. 1) was chosen for limiting dilution analysis as described in Methods. The CTL precursor frequency is given as the number of specific CTL per $10^{6}$ PBMCs in the lower right hand corner of each panel. (A) Patient-1, peptide 6; $(B)$ normal8 , peptide 2 .

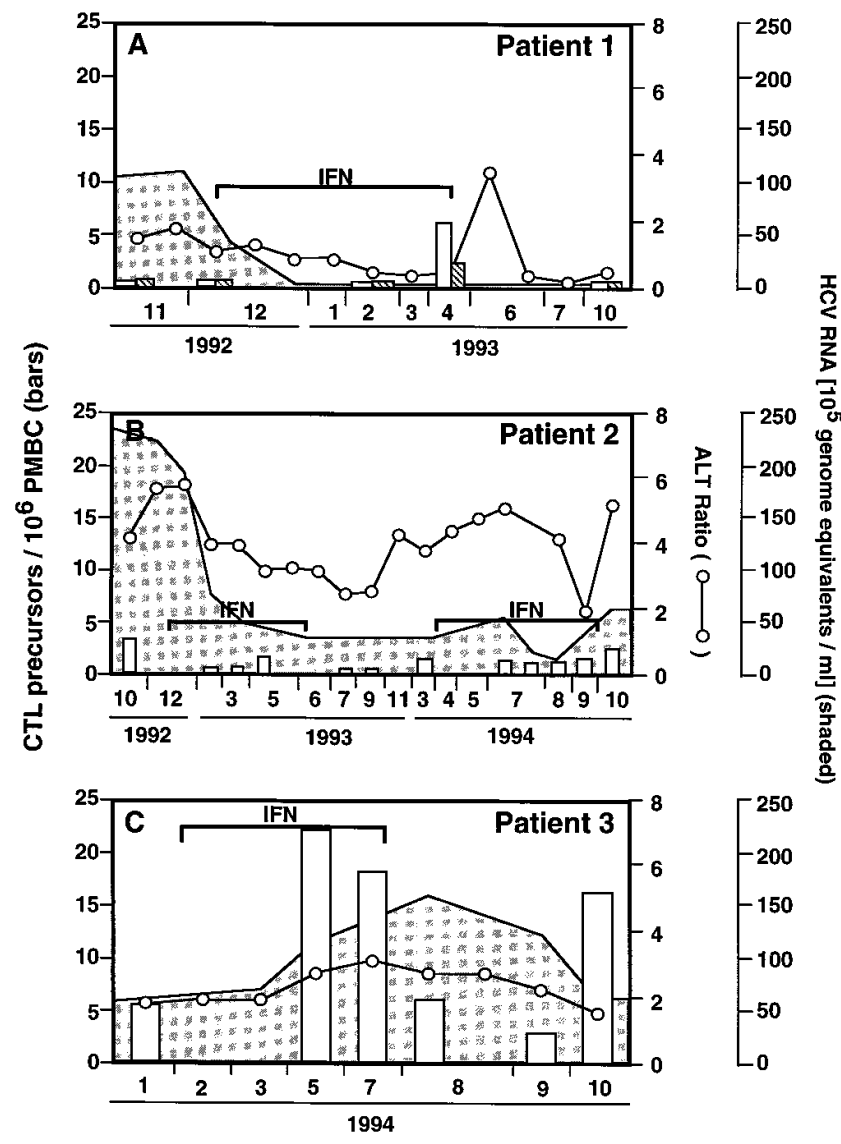

Figure 3. Serial analysis of the $\mathrm{HCV}$ epitope-specific CTL precursor frequency in patients $1(A), 2(B)$, and $3(C)$. The open circles display serum ALT ratio (ALT activity divided by the upper limit of the normal range), the shaded area reflects the amount of HCV RNA (genome equivalents $\times 10^{5} / \mathrm{ml}$ ) detected by bDNA analysis in the peripheral blood. Frequency of CTL specific for peptide 2 (Core 131) $(\$)$ and peptide 6 (NS3 1406) ( $\square$ ). All limiting dilution analyses were done in the same experiment. 


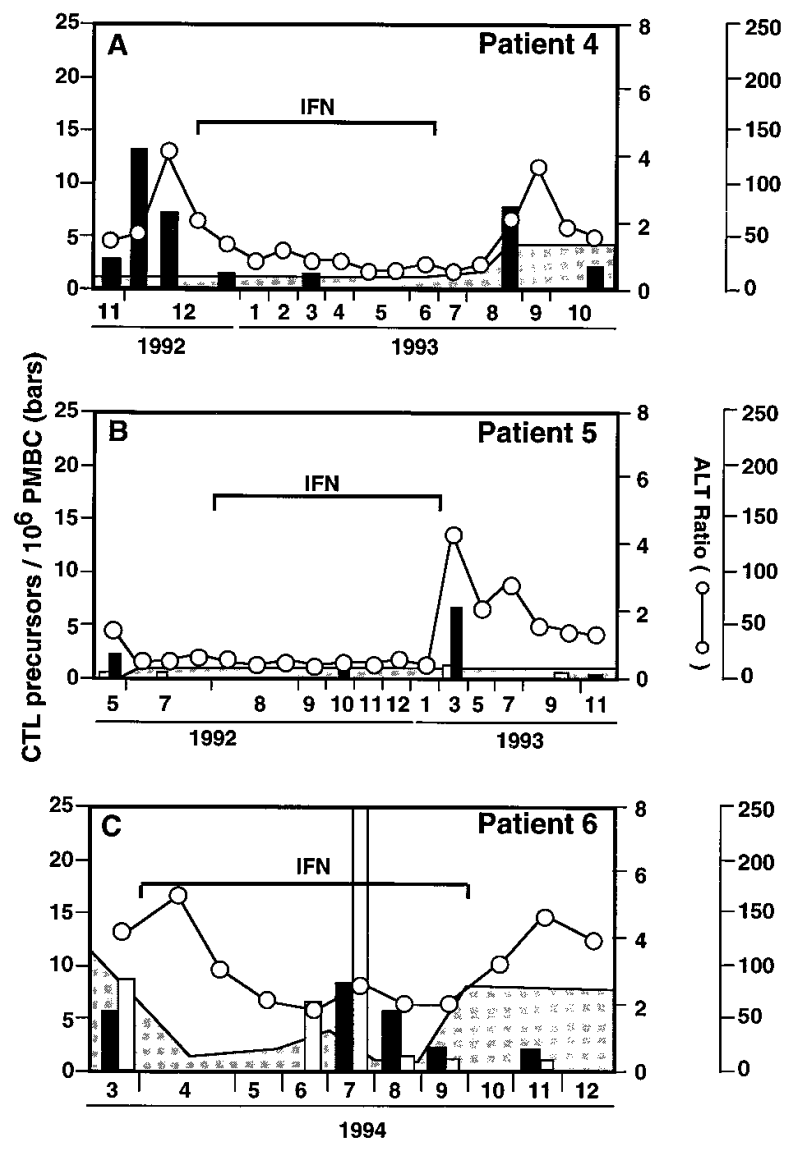

Figure 4. Serial analysis of the HCV epitope-specific CTL precursor frequency in patients $4(A), 5(B)$, and $6(C)$. The open circles display serum ALT ratio (ALT activity divided by the upper limit of the normal range), the shaded area reflects the amount of HCV RNA (genome equivalents $\times 10^{5} / \mathrm{ml}$ ) detected by bDNA analysis in the peripheral blood. Frequency of CTL specific for peptide 4 (NS3 1073) (ם) and peptide 6 (NS3 1406) ( $\square$ ). All limiting dilution analyses were done in the same experiment.

\section{Results}

Analysis of the CTL response to multiple HCV epitopes. To identify patients whose CTL responses to $\mathrm{HCV}$-derived epitopes were strong enough to warrant CTL precursor frequency analysis longitudinally by limiting dilution analysis, we screened all patients before interferon therapy with a panel of 10 predefined HCV-derived peptides. Using a microwell peptide stimulation strategy with eight replicate cultures per peptide, we demonstrated that most of the patients with chronic hepatitis C displayed a characteristic multispecific CTL response (Fig. 1). A CRI-P of at least 3 SDs above the average CRI-P obtained in controls was observed in all patients. In total, 43 out of 90 (46\%) possible CTL responses were positive in the patient group (Fig. 1) as oppposed to 5 out 150 (3\%) possible CTL responses in the controls (not shown). Since we have recently described that the total CRI, which represents the sum of all CRI-P per patient, is inversely associated with viral load (29), and since interferon is thought to have antiviral as well as immunmodulatory effects, we were therefore interested in analyzing the relationship between CTL response, disease activity, and viral load longitudinally during interferon therapy in indi-
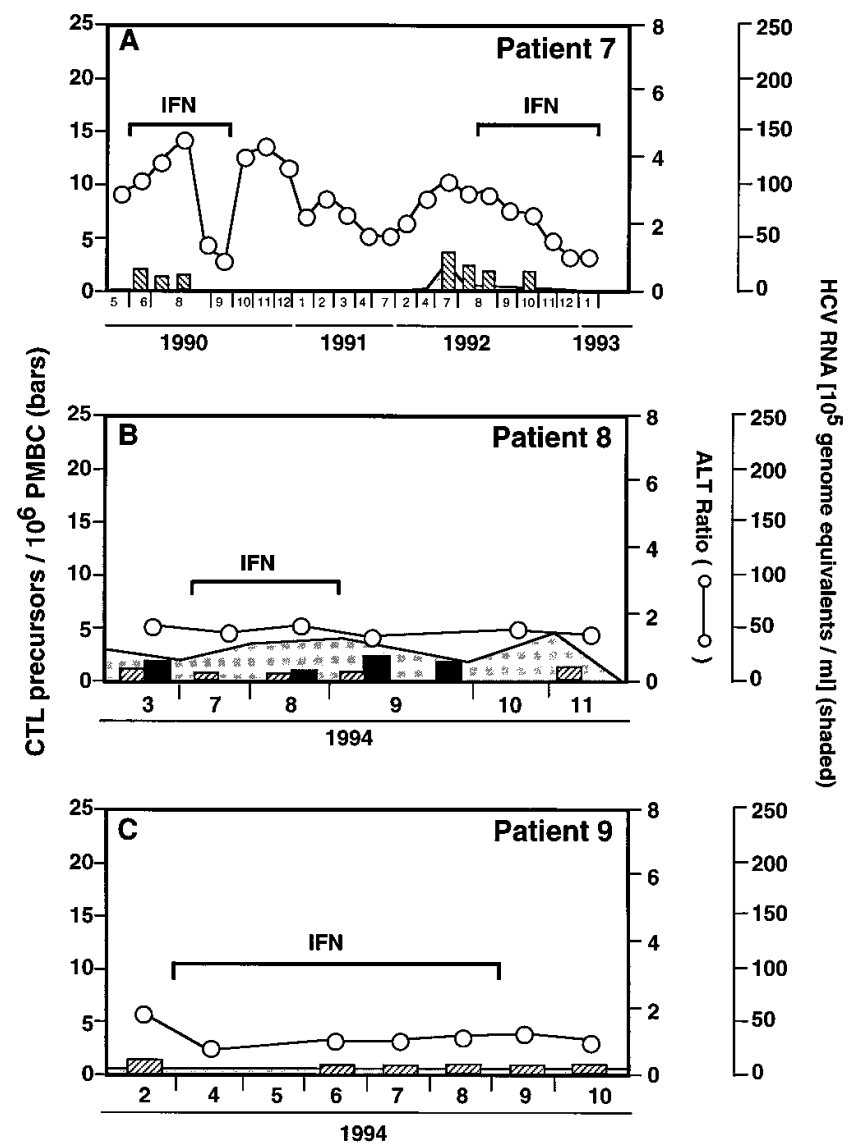

Figure 5. Precursor frequency of CTL specific for HCV-derived peptides $1($ Core 35) $(\square), 2$ (Core 131) $(\mathbb{\nabla})$, and 4 (NS3 1073) (ם) in patients $7(A), 8(B)$, and $9(C)$. The open circles display serum ALT ratio (ALT activity divided by the upper limit of the normal range), the shaded area reflects the amount of HCV RNA (genome equivalents $\times 10^{5} / \mathrm{ml}$ ) detected by bDNA analysis in the peripheral blood.

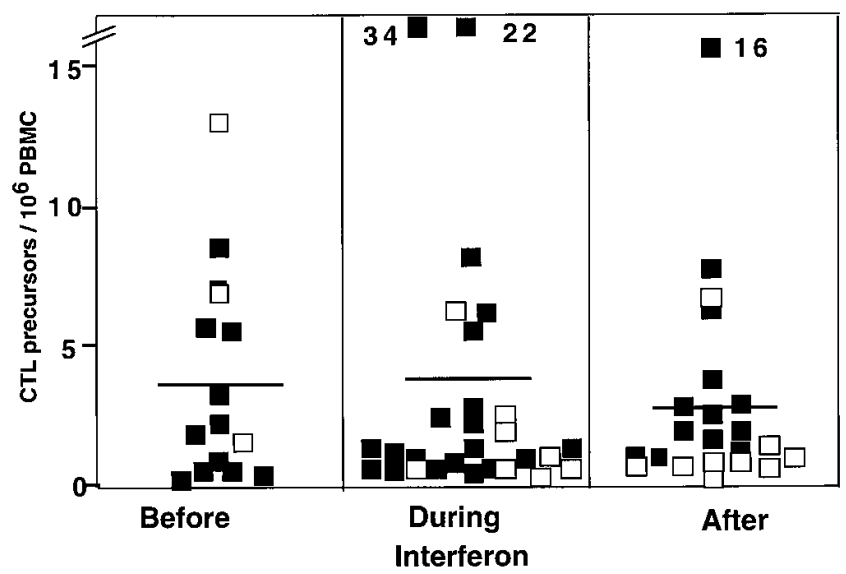

Figure 6. Precursor frequency of CTL specific for HCV-derived peptides 1 (Core 35), 2 (Core 131), 4 (NS3 1073), and 6 (NS3 1406) in all nine $\mathrm{HCV}$-infected patients before, during, and after interferon therapy. Filled squares represent the CTL precursor frequency, given as the number of specific CTL per $10^{6} \mathrm{PBMCs}$, in patients with high viral load; i.e., HCV RNA was detectable by bDNA analysis. Open squares represent the CTL precursor frequency in patients with low viral load; i.e., HCV RNA was undetectable by bDNA analysis. The mean CTLpf for all of the peptides in each group is indicated by a horizontal line. 
vidual patients. For each patient, one or two of the peptides that were best recognized (usually peptides 1 and 2 from the core protein and peptides 4 and 6 from the NS3 protein), displaying strong CTL response indices (underlined in Fig. 1), were chosen for CTLpf analysis (see below).

Relative strength of the CTL response to HCV and influenza virus matrix peptides in patients and controls. To compare the degree of sensitization to HCV and influenza virus (as a recall antigen), simultaneous limiting dilution analysis was performed to determine the CTLpf for $\mathrm{HCV}$ and influenza matrix peptides in three $\mathrm{HCV}$ patients and three normal controls. HCV- and influenza peptide-specific CTLpf's observed in a representative patient and a representative control (using the HCV peptide for which a high CTLp $f$ was observed for each subject) are displayed in Fig. 2. Note that there are more influenza-specific CTL precursors than HCV-specific CTL precursors in the chronically infected patient and that essentially no $\mathrm{HCV}$-specific CTL precursors were detectable in the uninfected control (i.e., $<1$ in $2 \times 10^{6}$ PBMCs). The HCV- and influenza virus-specific CTLp $f$ in all six subjects studied are summarized in Table III. Importantly, all three patients displayed fewer $\mathrm{HCV}$-specific CTL precursors for the HCV peptides they recognized efficiently in the screening assay (Fig. 1) than for the influenza recall antigen. Table III also illustrates that, despite the impressive degree of HCV peptide-inducible cytolytic activity illustrated in Fig. 1, the number of HCV-specific CTL precursors is actually quite low in these chronically infected patients, as we have previously reported (12).

Longitudinal analysis of HCV-specific CTL precursor frequency, disease activity, and viral load during interferon therapy. To examine the relationship between $\mathrm{HCV}$-specific CTLp $f$ and both disease activity and viral load, we studied the CTLp $f$ for one or two epitopes per patient at 4-12 time points before, during, and after interferon therapy. For each patient, $\mathrm{HCV}$-derived peptides that were recognized strongly in the screening assay (Fig. 1) were chosen for CTLpf analyses. For patients 2, 5, and 8, CTLpf for peptides that were less strongly recognized were also studied. As shown in Fig. 3, $A$ and $B$ and Fig. $4 C$, three (patients 1,2 , and 6) responded to interferon with rapid and profound decreases in viral load (shaded areas).

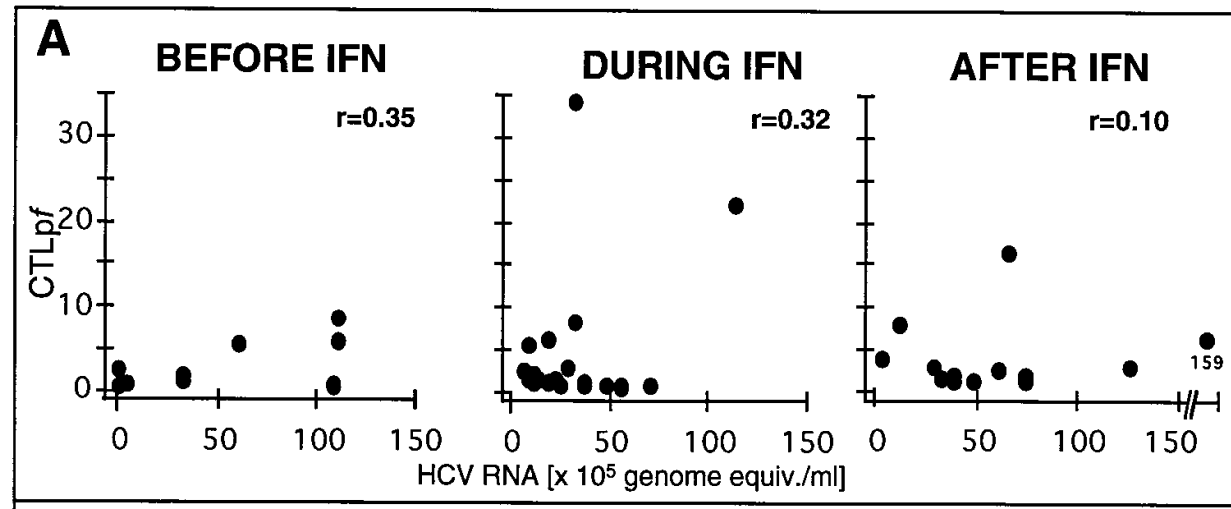

B
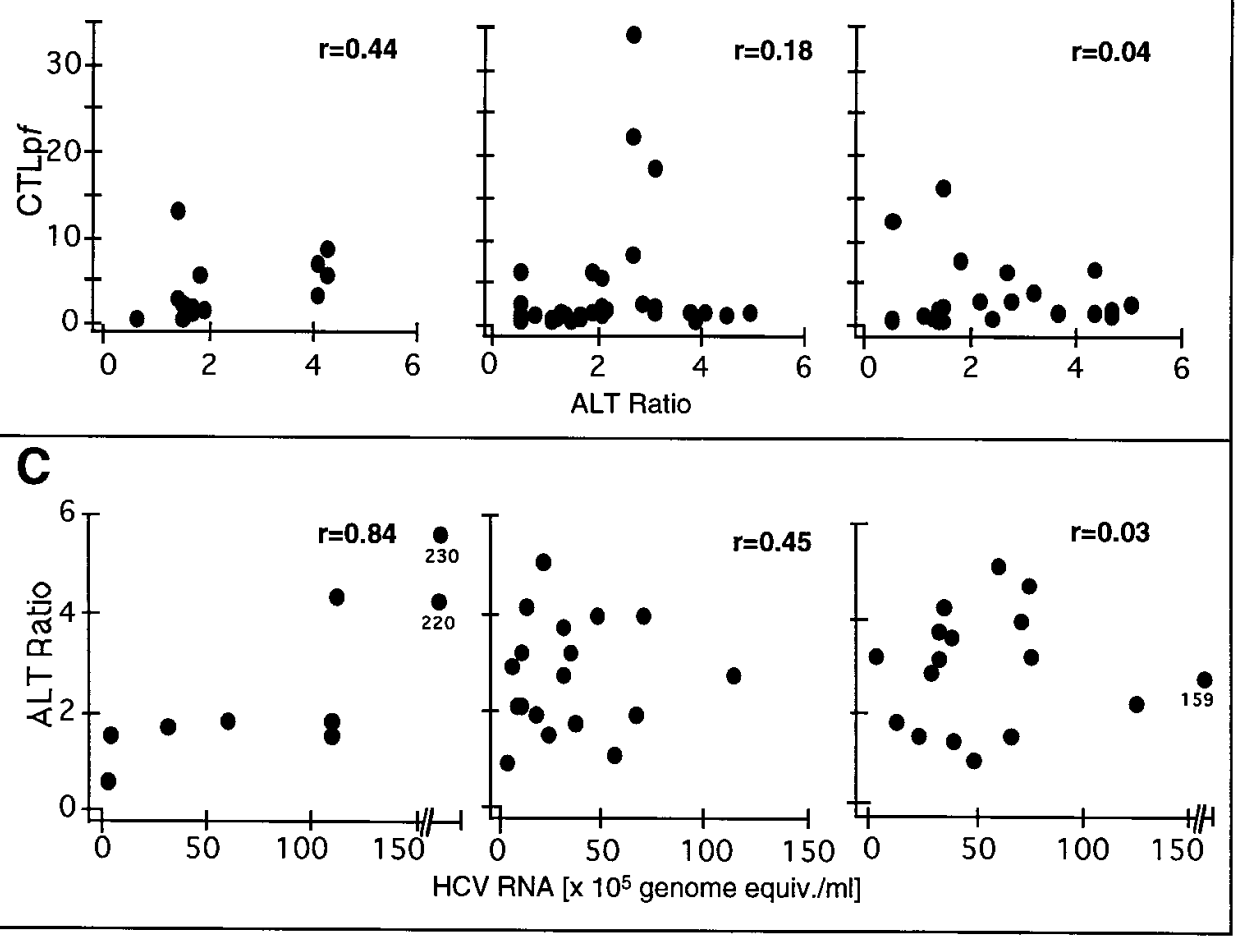

Figure 7. (A) Comparison of the frequency of CTL precursors (per $10^{6}$ PBMCs) specific for peptides 1 (Core 35), 2 (Core 131), 4 (NS3 1073), and 6 (NS3 1406) with serum HCV RNA content determined by bDNA analysis before, during, and after interferon therapy. If $\mathrm{HCV}$ RNA was undetectable by bDNA analysis, but detectable by PCR, the data were not included in this figure but are shown in Fig. 8. $r=$ correlation coefficient. $(B)$ Comparison of the frequency of CTL precursors specific for the same epitopes with serum ALT activity (the ALT ratio represents ALT activity divided by the upper limit of normal). (C) Comparison of serum ALT ratio and HCV RNA content. 
Importantly, the HCV-specific CTLpf (bars) did not change during this dynamic flux in viral load, indicating that CTLindependent mechanisms were probably responsible for the antiviral effect of interferon in these patients. In one atypical patient (patient 3) the HCV-specific CTLpf increased approximately fourfold during interferon therapy and fell back to baseline when treatment was stopped (Fig. $3 C$ ). Nonetheless, serum HCV RNA levels rose paradoxically during this period, indicating that neither the CTL response nor interferon therapy was able to control the viral burden in this individual. Note that serum ALT activity did not change despite the fluctuations in viral load and CTLp $f$ in this patient.

Five (patients 1,2, 4, 5, and 6) displayed flares in serum ALT activity, defined as a greater than twofold increase of serum ALT activity during a period of $2 \mathrm{mo}$, either before initiation of therapy (Fig. $4 A$ ) or after its withdrawal (Fig. 3, $A$ and $B$, and $4, A-C)$. It is noteworthy that CTLpf activity appeared to increase just before or concomitant with the disease flares in four out of six instances in three of these five (patients 1, 4, and 5), suggesting that the CTL response may have played a role in these episodes. However, sharp increases in CTLpf were also observed in patients 3 (Fig. $3 C$ ) and 6 (Fig. $4 C$ ) without any associated changes in serum HCV RNA or ALT activity, and wide fluctuations in serum ALT activity observed in patient 7 were not associated with concomitant changes in CTLpf or viral load (Fig. $5 A$ ). Patients 8 and 9 displayed minimal or no changes in HCV-specific CTLpf or serum HCV RNA levels over a similar observation period (Fig. 5, $A$ and $B$ ).

$H C V$-specific CTL precursor frequency is not enhanced during interferon therapy and, on a cross-sectional basis, does not correlate with disease activity or viral load. The foregoing results demonstrate that interferon treatment did not enhance the peripheral blood HCV-specific CTL response in these patients. This was confirmed when all patients were analyzed cross-sectionally before, during, and after interferon therapy for HCV-specific CTLpf. As shown in Fig. 6, the mean HCVspecific CTLp $f$ did not change significantly from pretreatment values during or after interferon treatment. Reflecting these observations, the HCV epitope-specific CTL precursor frequency did not correlate with either serum HCV RNA content as a measurement of viral load (Fig. $7 A$ ) or the serum ALT activity as a measurement of disease activity (Fig. $7 \mathrm{~B}$ ) before, during, or after interferon therapy. Finally, the serum HCV RNA content correlated with serum ALT activity in this group of patients before interferon treatment, although this correlation disappeared with interferon therapy (Fig. 7 C).

To determine if important correlations between viral load and CTLp $f$ or ALT may be masked by the low sensitivity of the bDNA assay $\left(>3.5 \times 10^{5}\right.$ genome equivalents $\left./ \mathrm{ml}\right)$, the bDNA-negative serum samples were also analyzed by semiquantitative PCR. However, no linear correlation was found between HCV CTLp $f$ and HCV RNA content even at the low levels detectable by this technique (Fig. $8 B$ ).

\section{Discussion}

The current study was performed to examine the basis for $\mathrm{HCV}$ persistence in the face of a multispecific peripheral blood CTL response in patients with chronic hepatitis. The results can be summarized as follows: first, chronically infected patients display fewer HCV-specific CTL precursors in their pe-
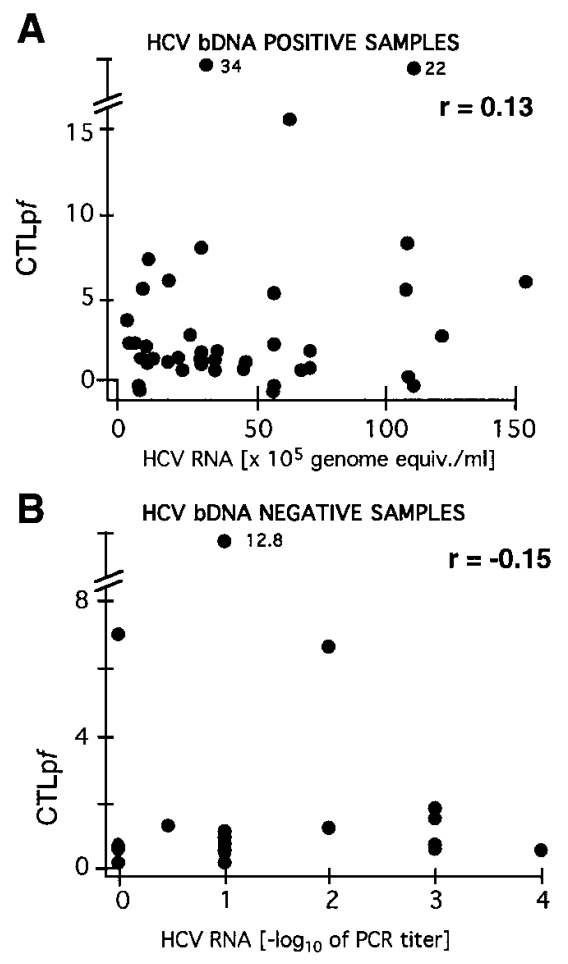

Figure 8. (A) Comparison of the frequency of CTL precursors (per $10^{6}$ PBMCs) specific for peptides 1 (Core 35), 2 (Core 131), 4 (NS3 1073), and 6

(NS3 1406) with serum HCV RNA content determined by bDNA analysis. $\mathrm{r}=$ correlation coefficient. ( $B$ ) Comparison of the frequency of CTL precursors (per $10^{6}$ PBMCs) specific for the same peptides with serum $\mathrm{HCV}$ RNA content in bDNA-negative samples determined by semiquantitative PCR before, during, and after interferon therapy. The negative logarithm (base 10) of the highest

serum dilution still yielding a positive signal by PCR is given as the HCV RNA titer for each sample.

ripheral blood than influenza-specific CTL. Assuming that the CTL responses we monitored in this study are representative of the overall strength of the CTL response to both of these viruses, this suggests that the active CTL response to an ongoing $\mathrm{HCV}$ infection in these patients is not as strong as their recall response to a previous influenza infection. This may explain why HCV is commonly persistent while influenza is not. Second, although HCV-specific peripheral CTLpf increased before flares in liver disease activity in a few patients, this relationship was not absolute, apparently reflecting the indolent nature of the disease in most of the patients we studied or compartmentalization of the CTL in the liver. Third, the HCV-specific CTLp $f$ did not correlate with viral load; in fact, the viral burden actually increased in the face of increasing CTLp $f$ in one patient, emphasizing the ineffectiveness of the CTL response against single $\mathrm{HCV}$ epitopes in these patients. Finally, in some subjects interferon treatment was associated with a reduction in viral load without enhancing the CTL response or inducing liver disease, suggesting that HCV may be susceptible to control by noncytopathic antiviral mechanisms that can be induced by interferon but are not spontaneously activated in these chronically infected patients.

These results suggest that the chronically infected patients mount a CTL response to HCV that may be quantitatively insufficient for viral clearance, but is likely to kill some of the infected hepatocytes, thereby causing chronic hepatitis. The reason why most patients mount an apparently ineffective CTL response to $\mathrm{HCV}$ is unclear. Global immunosuppression can be eliminated based on the normal CTLp $f$ these patients display to an unrelated viral antigen. Thymic deletion of HCVspecific $\mathrm{T}$ cells is unlikely since all of these patients were in- 
fected as adults. CTL exhaustion due to antigen hyperstimulation is unlikely since the viral burden during HCV infection is not especially high. Conceivably, HCV might interfere with antigen processing or presentation by the hepatocyte, thereby diminishing its visibility to the immune system sufficiently to hamper development of an immune response; however, there is no direct evidence for this hypothesis in the literature at this time. Alternatively, it is possible that the low number of $\mathrm{HCV}$ specific CTL precursors in the peripheral blood does not reflect conditions in the liver (15-17). If this is true, however, it implies that the cytolytic function of the intrahepatic HCVspecific CTL is not sufficient to kill or cure all of the infected cells in the liver even if the CTL response is vigorous.

Along these lines, based on evidence from a transgenic mouse model, we have recently suggested that hepatitis B virus (HBV)-specific CTL may control HBV infection not only by killing infected hepatocytes but also by inhibiting HBV replication by secreting certain antiviral cytokines when they recognize antigen $(30,31)$. If this or related potentially curative antiviral pathways are required for viral clearance to be complete in an organ with as many infectible cells as the liver, viruses that are either intrinsically resistant to noncytolytic control or that induce an immune response that does not produce the corresponding antiviral cytokines would have a survival advantage. The current data suggest that HCV may fall into one of these categories, and further studies should be done to pursue this hypothesis.

Finally, one must consider the possibility that HCV may have mutated and escaped the CTL response to the corresponding epitopes in the chronically infected patients we studied, and the response we measured is weak due to a lack of continuous stimulation by the original antigen. Furthermore, some patients did not display a CTL response to epitopes that should be encoded by the infecting virus as predicted by HCV genotyping. Others responded to $\mathrm{HCV}-1$-derived peptides that were not identical with the predicted sequence encoded by their own viral genotypes. These very interesting observations are currently under investigation at the nucleotide sequence level, especially since emergence of a CTL escape variant of $\mathrm{HCV}$ has been reported in a chronically infected chimpanzee (18).

Collectively, these results and the published database suggest that the CTL response probably contributes to disease pathogenesis but is not vigorous enough to eradicate the virus during chronic HCV infection in most patients. The current study emphasizes that the peripheral CTL precursor frequency to individual HCV epitopes is very low in the chronically infected patients we studied. The reason for the failure to mount a stronger epitope-specific CTL response is unclear at this time. If the peripheral CTL response reflects the HCV-specific CTLp $f$ in the intrahepatic lymphomononuclear cell infiltrate, the total number of HCV-specific CTL in the chronically infected liver may simply be too low to clear the virus from all of the infected cells. It is premature at this time to conclude that HCV cannot be controlled by CTL under any circumstances, however, even though most of the patients studied were not able to clear the virus completely and only a few displayed sharp changes in liver disease activity. Quantitation of multispecific CTL responses in patients who recover spontaneously from acute $\mathrm{HCV}$ infection is needed to better understand the role of the CTL response in HCV clearance and disease pathogenesis.

\section{Acknowledgments}

We thank Dr. James Koziol, Division of Biomathematics, The Scripps Research Institute, for statistical analysis and Dr. Andrew Conrad for HCV genotyping. We also thank Linda Wilkes, Julie Hansen, Kay Waite, Sue Dastrup, and Priscilla Crisler for assistance in recruiting patients, Colleen Cunningham for drawing the blood and coordinating clinical visits, Kendis Cox and Tony Mondala for help with processing blood samples, and Bonnie Weier for manuscript preparation.

This study was supported by grants AI-20001 and RR-00833 from the National Institutes of Health (NIH), the Sam and Rose Stein Endowment Fund, and a grant from Cytel Corporation. B. Rehermann was also supported by grants Re1017/1-1 and Re1017/2-1 from the Deutsche Forschungsgemeinschaft, Bonn, Germany. K.M. Chang was supported by NIH training grant 2T32DKO7202 through the University of California, San Diego (San Diego, CA), and the American Liver Foundation's Amgen Postdoctoral Research Fellowship Award. This is manuscript number 9686-MEM from the Scripps Research Institute.

\section{References}

1. Choo, Q.-L., G. Kuo, A.J. Weiner, L.R. Overby, D.W. Bradley, and M. Houghton. 1989. Isolation of a cDNA clone derived from a blood-borne nonA, non-B viral hepatitis genome. Science (Wash. DC). 244:359-362.

2. Houghton, M., A. Weiner, J. Han, G. Kuo, and Q.-L. Choo. 1990. Molecular biology of the hepatitis $\mathrm{C}$ virus: implications for diagnosis, development and control of viral disease. Hepatology. 14:381-388.

3. Kuo, G., Q.-L. Choo, H.J. Alter, G.I. Gitnick, A.G. Redeker, R.H. Purcell, T. Miyamura, J.L. Dienstag, M.J. Alter, C.E. Stevens, et al. 1989. An assay for circulating antibodies to a major etiologic virus of human non-A, non-B hepatitis. Science (Wash. DC). 244:362-364.

4. Choo, Q.-L., A.J. Weiner, L.R. Overby, G. Kuo, M. Houghton, and D.W. Bradley. 1990. Hepatitis C virus: the major causative agent of viral non-A, nonB hepatitis. Br. Med. Bull. 46:423-441.

5. Saito, I., T. Miyamura, A. Ohbayashi, H. Harada, T. Katayama, S. Kikuchi, Y. Watanabe, S. Koi, M. Onji, Y. Ohta, Q.-L. Choo, M. Houghton, and G. Kuo. 1990. Hepatitis C virus infection is associated with the development of hepatocellular carcinoma. Proc. Natl. Acad. Sci. USA. 87:6547-6549.

6. Nishioka, K., J. Watanabe, S. Furuta, E. Tanaka, S. Iino, H. Suzuki, T. Tsuji, M. Yano, G. Kuo, Q.-L. Choo, et al. 1991. A high prevalence of antibody to the hepatitis $\mathrm{C}$ virus in patients with hepatocellular carcinoma in Japan. Cancer (Phila.). 67:429-433.

7. Zinkernagel, R.M., and P.C. Doherty. 1979. MHC-restricted cytotoxic T cells: studies on the biological role of polymorphic major transplantation antigens determining T-cell restriction-specificity. Adv. Immunol. 19:51-74.

8. Chisari, F.V., and C. Ferrari. 1996. Immunobiology and pathogenesis of viral hepatitis. In Viral Pathogenesis. N. Nathenson, R. Ahmed, F. GonzalezScarano, D. Griffin, K. Holmes, F.A. Murphy, and H.L. Robinson, editors. J.B. Lippincott Co., Philadelphia, PA. In press.

9. Cerny, A., C. Ferrari, and F.V. Chisari. 1994. The class I restricted cytotoxic $\mathrm{T}$ lymphocyte response to predetermined epitopes in the hepatitis $\mathrm{B}$ and $\mathrm{C}$ viruses. In Current Topics in Microbiology and Immunology. M.B.A. Oldstone, editor. Springer-Verlag GmbH \& Co., Heidelberg, Germany. 169-186.

10. Shirai, M., H. Okada, M. Nishioka, T. Akatsuka, C. Wychowski, R. Houghten, C.D. Pendelton, S.M. Feinstone, and J.A. Berzofsky. 1994. An epitope in hepatitis $\mathrm{C}$ virus core region recognized by cytotoxic $\mathrm{T}$ cells in mice and humans. J. Virol. 68:3334-3342.

11. Kita, H., T. Moriyama, T. Kaneko, I. Harase, M. Nomura, H. Miura, I. Nakamura, Y. Yazaki, and M. Imawari. 1993. HLA-B44-restricted cytotoxic T lymphocyte recognizing an epitope on hepatitis $\mathrm{C}$ virus nucleocapsid protein. Hepatology. 18:1039-1044.

12. Cerny, A., J.G. McHutchison, C. Pasquinelli, M.E. Brown, M.A. Brothers, B. Grabscheid, P. Fowler, M. Houghton, and F.V. Chisari. 1995. Cytotoxic $\mathrm{T}$ lymphocyte response to hepatitis $\mathrm{C}$ virus-derived peptides containing the HLA A2.1 binding motif. J. Clin. Invest. 95:521-530.

13. Battegay, M., J. Fikes, A.M. Di Bisceglie, P.A. Wentworth, A. Sette, E. Celis, W.-M. Ching, A. Grakoui, C.M. Rice, K. Kurokohchi, J.A. Berzofsky, J.H. Hoofnagle, S.M. Feinstone, and T. Akatsuka. 1995. Patients with chronic hepatitis $\mathrm{C}$ have circulating cytotoxic $\mathrm{T}$ cells which recognize hepatitis $\mathrm{C}$ virusencoded peptides binding to HLA-A2.1 molecules. J. Virol. 69:2462-2470.

14. Shirai, M., T. Arichi, M. Nishioka, T. Nomura, K. Ikeda, K. Kawanishi, V.H. Engelhard, S.M. Feinstone, and J.A. Berzofsky. 1995. CTL responses of HLA-A2.1-transgenic mice specific for hepatitis $\mathrm{C}$ viral peptides predict epitopes for CTL of humans carrying HLA-A2.1. J. Immunol. 154:2733-2742.

15. Koziel, M.J., D. Dudley, J.T. Wong, J. Dienstag, M. Houghton, R. Ral- 
ston, and B.D. Walker. 1992. Intrahepatic cytotoxic T lymphocytes specific for hepatitis C virus in persons with chronic hepatitis. J. Immunol. 149:3339-3344.

16. Koziel, J.M., D. Dudley, N. Afdhal, Q.L. Choo, M. Houghton, R. Ralston, and B.D. Walker. 1993. Hepatitis C virus (HCV)-specific cytotoxic T lymphocytes recognize epitopes in the core and envelope proteins of HCV.J. Virol. 67:7522-7532.

17. Koziel, M.J., D. Dudley, N. Afdhal, A. Grakoul, C.M. Rice, Q.-L. Choo, M. Houghton, and B.D. Walker. 1995. HLA class I-restricted cytotoxic T lymphocytes specific for hepatitis $\mathrm{C}$ virus. Identification of multiple epitopes and characterization of patterns of cytokine release. J. Clin. Invest. 96:2311-2321.

18. Weiner, A., A.L. Erickson, J. Kansopon, K. Crawford, E. Muchmore, A.L. Hughes, M. Houghton, and C.M. Walker. 1995. Persistent hepatitis C virus infection in a chimpanzee is associated with emergence of a cytotoxic T lymphocyte escape variant. Proc. Natl. Acad. Sci. USA. 92:2755-2759.

19. Simmonds, P. 1995. Variability of Hepatitis C Virus. Hepatology. 21: $570-583$

20. Mosmann, T.R. 1994. Cytokine pattern during the progression to AIDS. Science (Wash. DC). 265:193-194.

21. Vitiello, A., D. Marchesini, J. Furze, L.A. Sherman, and R.W. Chesnut. 1991. Analysis of the HLA-restricted influenza-specific cytotoxic T lymphocyte response in transgenic mice carrying a chimeric human-mouse class I major histocompatibility complex. J. Exp. Med. 173:1007-1015.

22. Choo, Q.L., K.H. Richman, J.H. Han, K. Berger, C. Lee, C. Dong, C. Gallegos, D. Coit, A. Medina-Selby, P.J. Barr, et al. 1991. Genetic organization and diversity of the hepatitis C virus. Proc. Natl. Acad. Sci. USA. 88:2451-2455.

23. Rehermann, B., D. Lau, J.H. Hoofnagle, and F.V. Chisari. 1996. Cytotoxic $\mathrm{T}$ lymphocyte responsiveness after resolution of chronic hepatitis $\mathrm{B}$ virus infection J. Clin. Invest. 97:1655-1665.

24. Wentworth, P.A., E. Celis, C. Crimi, S. Stitely, L. Hale, V. Tsai, H.M Serra, M.-F. del Guercio, B. Livingston, D. Alazard, et al. 1995. In vitro induction of primary, antigen-specific CTL from human peripheral blood mononuclear cells stimulated with synthetic peptides. Mol. Immunol. 32:602-612.

25. Fazekas, S., and S.T. Groth. 1982. The evaluation of limiting dilution assays. J. Immunol. Methods. 49:11-23.

26. Chomczynski, P., and N. Sacchi. 1987. Single-Step method of RNA isolation by acid guanidinium thiocyanate-phenol-chloroform extraction. Anal. Biochem. 162:156-159.

27. Chan, S.W., F. McOmish, E.C. Holmes, B. Dow, J.F. Peutherer, E. Follett, P.L. Yap, and P. Simmonds. 1992. Analysis of a new hepatitis C virus type and its phylogenetic relationship to existing variants. J. Gen. Virol. 73:1131-1141.

28. Stuyver, L., A. Wyseur, W. van Arnhem, F. Lunel, P. Laurent-Puig, J.M. Pawlotsky, B. Kleter, L. Bassit, J. Nkengasong, and L.J. van Doorn. 1995. Hepatitis $\mathrm{C}$ virus genotyping by means of $5^{\prime}-\mathrm{UR} /$ core line probe assays and molecular analysis of untypeable samples. Virus Res. 38:137-157.

29. Rehermann, B., K.-M. Chang, J. McHutchison, R. Kokka, M. Houghton, C.M. Rice, and F.V. Chisari. 1996. Differential cytotoxic T lymphocyte responsiveness to the hepatitis B and $\mathrm{C}$ viruses in chronically infected patients. $J$. Virol. In press.

30. Guidotti, L.G., T. Ishikawa, M.V. Hobbs, B. Matzke, R. Schreiber, and F.V. Chisari. 1996. Intracellular inactivation of the hepatitis B virus by cytotoxic T lymphocytes. Immunity. 4:35-36.

31. Tsui, L.V., L.G. Guidotti, T. Ishikawa, and F.V. Chisari. 1995. Post-transcriptional clearance of hepatitis B virus RNA by cytotoxic T lymphocyte activated hepatocytes. Proc. Natl. Acad. Sci. USA. 92:12398-12402. 